\title{
Phylogeny, Distribution, and Pathogenicity of Lasiodiplodia Species Associated With Cankers and Dieback Symptoms of Persian Lime in Mexico
}

\author{
M. A. Bautista-Cruz, ${ }^{1}$ G. Almaguer-Vargas, ${ }^{1}$ S. G. Leyva-Mir, ${ }^{2}$ M. T. Colinas-León, ${ }^{1}$ K. C. Correia, ${ }^{3}$ \\ M. Camacho-Tapia, ${ }^{4}$ L. Robles-Yerena, ${ }^{1}$ S. J. Michereff, ${ }^{3}$ and J. M. Tovar-Pedraza ${ }^{5,}$ \\ ${ }^{1}$ Posgrado en Horticultura, Departamento de Fitotecnia, Universidad Autónoma Chapingo, Texcoco, 56230 Estado de México, Mexico; \\ ${ }^{2}$ Departamento de Parasitología Agrícola, Universidad Autónoma Chapingo, Texcoco, 56230 Estado de México, Mexico; ${ }^{3}$ Centro \\ de Ciências Agrárias e da Biodiversidade, Universidade Federal do Cariri, Crato, 63.133-610 Ceará, Brazil; ${ }^{4}$ Laboratorio Nacional \\ de Investigación y Servicio Agroalimentario y Forestal, Universidad Autónoma Chapingo, Texcoco, 56230 Estado de México, \\ Mexico; and ${ }^{5}$ Laboratorio de Fitopatología, Coordinación Culiacán, Centro de Investigación en Alimentación y Desarrollo, \\ Culiacán, 80110 Sinaloa, Mexico
}

\begin{abstract}
Persian lime (Citrus latifolia Tan.) is an important and widely cultivated fruit crop in several regions of Mexico. In recent years, severe symptoms of gummosis, stem cankers, and dieback were detected in the Persian lime-producing region in the states of Veracruz and Puebla, Mexico. The aims of this study were to identify the species of Lasiodiplodia associated with these symptoms, determine the distribution of these species, and test their pathogenicity and virulence on Persian lime plants. In 2015, symptomatic samples were collected from 12 commercial Persian lime orchards, and 60 Lasiodiplodia isolates were obtained. Fungal identification of 32 representative isolates was performed using a phylogenetic analysis based on DNA sequence data of the internal transcribed spacer

identified as Lasiodiplodia pseudotheobromae, Lasiodiplodia theobromae, Lasiodiplodia brasiliense, Lasiodiplodia subglobosa, Lasiodiplodia citricola, and Lasiodiplodia iraniensis. All Lasiodiplodia species of this study are reported for the first time in association with Persian lime in Mexico and worldwide. L. pseudotheobromae (46.9\% of isolates) was the most frequently isolated species followed by L. theobromae $(28.1 \%)$ and $L$. brasiliense $(12.5 \%)$. Pathogenicity on Persian lime young plants using a mycelial plug inoculation method showed that all identified Lasiodiplodia species were able to cause necrotic lesions and gummosis, but L. subglobosa, L. iraniensis, and L. pseudotheobromae were the most virulent.
\end{abstract} region and part of the translation elongation factor 1- $\alpha$ and $\beta$-tubulin genes. Sequence analyses were carried out using the Maximum Likelihood and Bayesian Inference methods. Six Lasiodiplodia species were

Keywords: Botryosphaeriaceae, Citrus latifolia, fungal diversity, pathogenicity, phylogenetic analysis

Mexico occupies the second place in world production of limes and lemons with a total of 2.4 million tonnes (Food and Agriculture Organization [FAO] 2016). Currently, this country is considered the main producer and exporter of Persian lime (Citrus latifolia Tan.) worldwide, with a cultivated area of 82,900 ha and a total production of 1.01 million tonnes (SIAP 2013). The main production area for Persian lime in Mexico is concentrated in the central coastal region of the Gulf of Mexico, and $46 \%$ of production is exported to the U.S.A., Europe, Canada, and Japan. Fruits are used fresh, and they are also used for the extraction of pectin and essential oils for foreign markets (Mendoza-Tornez et al. 2016). Dieback of Persian lime trees is a disease that decreases the production and longevity of orchards in the lime-producing region of the states of Puebla and Veracruz, Mexico, but the causative agents are unknown.

The Botryosphaeriaceae family (Dothideomycetes, Botryosphaeriales) includes 23 genera and 187 species, with cosmopolitan distribution on a broad range of woody hosts occurring as endophytes, saprobes, or destructive plant pathogens (Dissanayake et al. 2016; Phillips et al. 2013; Slippers and Wingfield 2007; Slippers et al. 2013). Several Botryosphaeriaceae species have been previously associated with citrus diseases, including Diplodia spp., Dothiorella spp., Neofusicoccum spp. (Adesemoye et al. 2014), Neoscytalidium spp. (Adesemoye et al. 2014; Mayorquin et al. 2016), and Lasiodiplodia spp. (Abdollahzadeh et al. 2010; Adesemoye et al. 2014;

${ }^{\dagger}$ Corresponding author: J. M. Tovar-Pedraza; juan.tovar@ciad.mx

The author(s) declare no conflict of interest.

Accepted for publication 2 November 2018.

() 2019 The American Phytopathological Society
Al-Sadi et al. 2013; Alves et al. 2008; Coutinho et al. 2017; Davis et al. 1987; Ferrari et al. 1996; Guajardo et al. 2018; Linaldeddu et al. 2015).

The main features that distinguish the genus Lasiodiplodia from other closely related genera are the presence of pycnidial paraphyses and longitudinal striations on mature conidia (Abdollahzadeh et al. 2010). Currently, the identification of Lasiodiplodia species by morphology is impossible, and it is necessary to use DNA sequence data, preferably combining sequences from multiple loci, such as internal transcribed spacer (ITS), $\beta$-tubulin (BT2), and translation elongation factor $1-\alpha$ (TEF1) genes, for accurate identification (Chen et al. 2014a, 2014b; Coutinho et al. 2017; Machado et al. 2014; Phillips et al. 2013; Rosado et al. 2016; Slippers et al. 2014; Zhou et al. 2015).

Previous studies have associated Lasiodiplodia spp. with symptoms of dieback, gummosis, and canker in a wide diversity of Citrus species, including sweet orange (Citrus sinensis Osbeck) in the U.S.A., Venezuela, Oman, Algeria, and Brazil (Al-Sadi et al. 2013; Coutinho et al. 2017; Davis et al. 1987; Ferrari et al. 1996; Linaldeddu et al. 2015); acid lime (Citrus aurantifolia S.), sweet lime (Citrus limettioides Tan.), and mandarin (Citrus reticulata Blanco) in Oman (Al-Sadi et al. 2013); sour orange (Citrus aurantium L.) in the U.S.A. and Suriname (Alves et al. 2008; Davis et al. 1987); grapefruit (Citrus paradisi Macfad) in the U.S.A. and Venezuela (Davis et al. 1987; Ferrari et al. 1996); lemon (Citrus limon L. Osbeck) in Venezuela and Chile (Ferrari et al. 1996; Guajardo et al. 2018); and Citrus species in Iran and the U.S.A. (Abdollahzadeh et al. 2010; Adesemoye et al. 2014). However, there are no studies of Lasiodiplodia species affecting Persian lime trees worldwide.

The aims of this study were to identify the species of Lasiodiplodia associated with these symptoms by phylogenetic inference, determine the distribution of these species, and test their pathogenicity and virulence on young Persian lime plants. 


\section{Materials and Methods}

Field survey. In September 2015, a survey was conducted in 12 commercial Persian lime orchards distributed in the states of Puebla and Veracruz in the central coastal region of the Gulf of Mexico. Symptomatic plant tissues (4 to 14 years old) showing stem cankers, gummosis, and branches dieback were collected (Fig. 1). Disease incidence was calculated using the following formula:
$I(\%)=(n i / N) \times 100$, where $I=$ incidence of disease, $n i=$ total number of symptomatic trees, and $N=$ total number of evaluated trees.

Isolates. Fragments of branches ( 4 to $5 \mathrm{~mm}$ in diameter) were collected from the margin between necrotic and healthy tissues, surface sterilized with $1 \%$ sodium hypochlorite for $1 \mathrm{~min}$, rinsed three times with sterile distilled water, and dried on sterile paper. Fragments were placed in petri plates containing $2 \%$ potato dextrose agar (PDA;
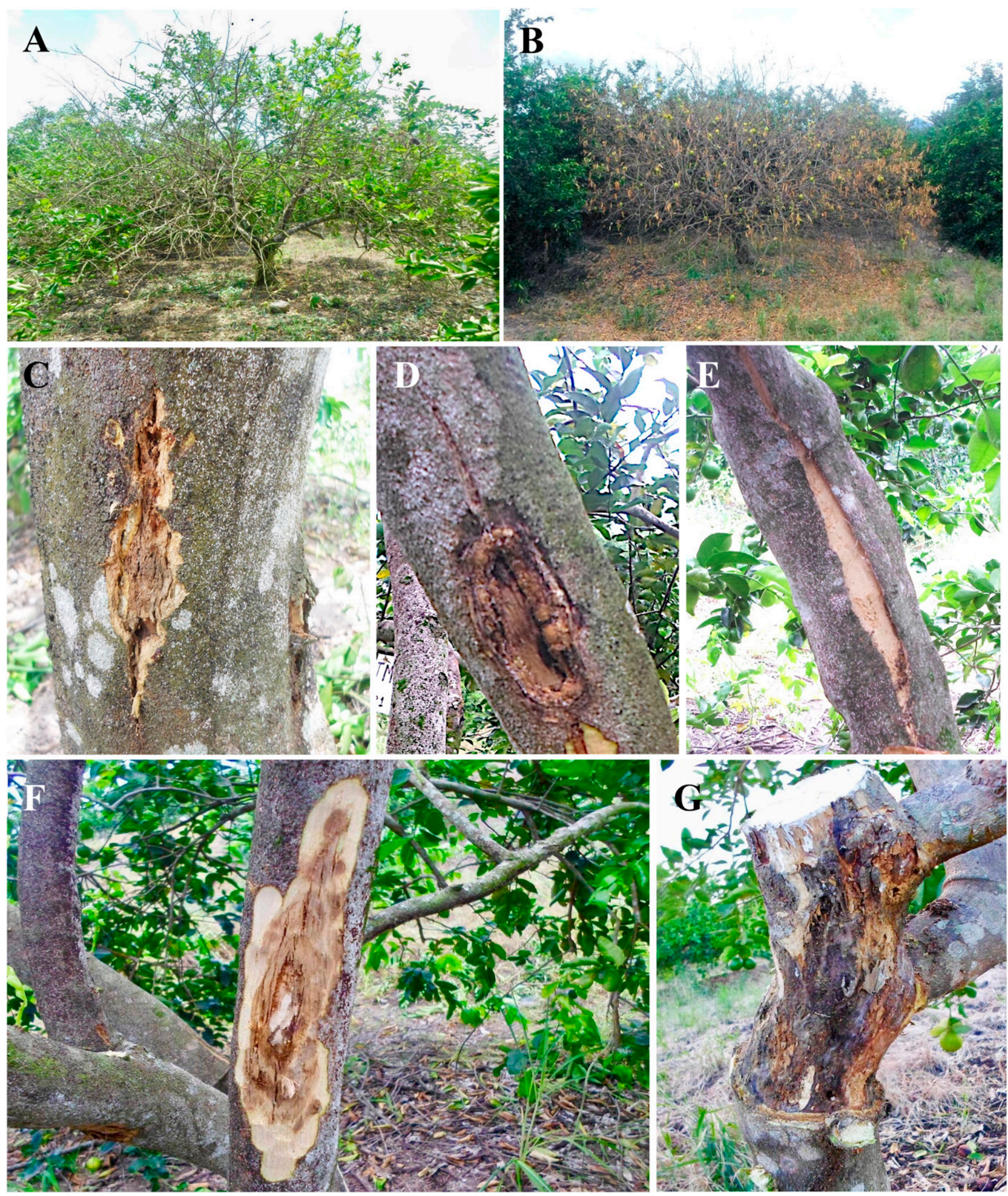

Fig. 1. Symptoms of dieback and canker of Persian lime (Citrus latifolia) associated with Lasiodiplodia spp. in Mexico. A, Tree showing dieback of branches. B, Tree exhibiting severe defoliation. C and D, Sunken cankers on branches. E, Branch with longitudinal cracking of the bark. F, Branch with canker and internal tissue necrosis. G, Diseased trunk with severe wood necrosis. 
Difco, Detroit, MI) supplemented with $0.5 \mathrm{~g} / \mathrm{L}$ streptomycin sulfate (Sigma-Aldrich Co, St. Louis, MO) and incubated at $25^{\circ} \mathrm{C}$ in the dark. Pure cultures were obtained by transferring hyphal tips from the colony margin onto fresh PDA and incubated at $25^{\circ} \mathrm{C}$ in the dark. The isolates used in this study were deposited in the Culture Collection of Phytopathogenic Fungi of the Department of Agricultural Parasitology at the Chapingo Autonomous University. Stock cultures were stored in $2.0-\mathrm{ml}$ cryovials in $15 \%$ glycerol at $-80^{\circ} \mathrm{C}$ and sterile water at $4^{\circ} \mathrm{C}$
DNA extraction, polymerase chain reaction amplification, and sequencing. Aerial mycelium from 6-day-old culture was scraped directly from the medium using a sterile spatula and placed in 2-ml microtubes. Total genomic DNA was extracted using a DNeasy Plant Mini Kit (Qiagen, Valencia, CA) following the manufacturer's recommendation. DNA concentrations were quantified using a NanoDrop Lite Spectrophotometer (Thermo Fisher Scientific, Madison, WI), and the samples were diluted to $100 \mathrm{ng} / \mu \mathrm{l}$ for polymerase chain reaction (PCR).

Table 1. GenBank accession numbers of DNA sequences of Lasiodiplodia spp. included in the phylogenetic study ${ }^{\mathrm{a}}$

\begin{tabular}{|c|c|c|c|c|c|c|}
\hline \multirow[b]{2}{*}{ Species } & \multirow[b]{2}{*}{ Isolate code } & \multirow[b]{2}{*}{ Host } & \multirow[b]{2}{*}{ Location } & \multicolumn{3}{|c|}{ GenBank accession number } \\
\hline & & & & ITS & TEF1 & BT2 \\
\hline Lasiodiplodia avicenniae & CMW41467 & Avicennia marina & South Africa & KP860835 & KP860680 & KP860758 \\
\hline Lasiodiplodia avicenniae & LAS199 (DNA) & Avicennia marina & South Africa & KU587957 & KU587947 & KU587868 \\
\hline Lasiodiplodia brasiliense & CMM4015 & Mangifera indica & Brazil & JX464063 & JX464049 & N/A \\
\hline Lasiodiplodia brasiliense & CMW35884 & Adansonia madagascariensis & Madagascar & KU887094 & KU886972 & KU887466 \\
\hline Lasiodiplodia brasiliense & $\mathrm{UACH} 257$ & Citrus latifolia & Mexico & MH277910 & MH286537 & MH279903 \\
\hline Lasiodiplodia brasiliense & UACH266 & Citrus latifolia & Mexico & MH277911 & MH286535 & MH279905 \\
\hline Lasiodiplodia brasiliense & UACH267 & Citrus latifolia & Mexico & MH277912 & MH286536 & MH279906 \\
\hline Lasiodiplodia brasiliense & $\mathrm{UACH} 269$ & Citrus latifolia & Mexico & MH277913 & MH286538 & MH279904 \\
\hline Lasiodiplodia brugulerae & CMW41470 & Bruguiera gymnorrhiza & South Africa & KP860833 & KP860678 & KP860756 \\
\hline Lasiodiplodia brugulerae & CMW42480 & Bruguiera gymnorrhiza & South Africa & KP860832 & KP860677 & KP860755 \\
\hline Lasiodiplodia caatinguensis & IBL271 & Anacardium occidentale & Brazil & KT154756 & KT154750 & KT154763 \\
\hline Lasiodiplodia caatinguensis & CMM1325 & Citrus sinensis & Brazil & KT154760 & КT008006 & KT154767 \\
\hline Lasiodiplodia chinensis & CGMCC3.18061 & Unknown & China & KX499889 & KX499927 & KX500002 \\
\hline Lasiodiplodia chinensis & CGMCC3.18044 & Vaccinium uliginosum & China & KX499875 & KX499913 & KX499988 \\
\hline Lasiodiplodia citricola & UACH262 & Citrus latifolia & Mexico & MH277948 & MH286541 & MH279934 \\
\hline Lasiodiplodia citricola & CBS124707 & Citrus sp. & Iran & GU945354 & GU945340 & KU887505 \\
\hline Lasiodiplodia citricola & IRAN1521C & Citrus sp. & Iran & GU945353 & GU945339 & KU887504 \\
\hline Lasiodiplodia crassispora & CBS118741 & Santalum album & Australia & DQ103550 & EU673303 & KU887506 \\
\hline Lasiodiplodia crassispora & CMW13488 & Eucalyptus urophylla & Venezuela & DQ103552 & DQ103559 & KU887507 \\
\hline Lasiodiplodia euphorbicola & СMМ3609 & Jatropha curcas & Brazil & KF234543 & KF226689 & KF254926 \\
\hline Lasiodiplodia euphorbicola & CMM3651 & Jatropha curcas & Brazil & KF234553 & KF226711 & KF254937 \\
\hline Lasiodiplodia exigua & BL184 & Retama raetam & Tunisia & KJ638318 & KJ638337 & N/A \\
\hline Lasiodiplodia exigua & CBS137785 & Retama raetam & Tunisia & KJ638317 & KJ638336 & KU887509 \\
\hline Lasiodiplodia gilanensis & IRAN1523C & Unknown & Iran & GU945351 & GU945342 & KU887511 \\
\hline Lasiodiplodia gilanensis & IRAN1501C & Unknown & Iran & GU945352 & GU945341 & KU887511 \\
\hline Lasiodiplodia gonubiensis & CBS115812 & Syzigium cordatum & South Africa & AY639595 & DQ103566 & DQ458860 \\
\hline Lasiodiplodia gonubiensis & CMW14078 & Syzigium cordatum & South Africa & AY639594 & DQ103567 & EU673126 \\
\hline Lasiodiplodia gravistriata & CMM4564 & Anacardium humile & Brazil & KT250949 & KT250950 & N/A \\
\hline Lasiodiplodia gravistriata & CMM4570 & Anacardium humile & Brazil & KT250948 & KT266814 & N/A \\
\hline Lasiodiplodia hyalina & CGMCC3.17975 & Acacia confusa & China & KX499879 & KX499917 & KX499992 \\
\hline Lasiodiplodia hyalina & CGMCC 3.18383 & Unknown & China & KY767661 & KY751302 & KY751299 \\
\hline Lasiodiplodia hormozganensis & IRAN1500C & Olea sp. & Iran & GU945355 & GU945343 & KU887515 \\
\hline Lasiodiplodia hormozganensis & IRAN1498C & Mangifera indica & Iran & GU945356 & GU945344 & KU887514 \\
\hline Lasiodiplodia iraniensis & IRAN1502C & Juglans sp. & Iran & GU945347 & GU945335 & KU887517 \\
\hline Lasiodiplodia iraniensis & IRAN1520C & Salvadora persica & Iran & GU945348 & GU945336 & KU887516 \\
\hline Lasiodiplodia iraniensis & $\mathrm{UACH} 275$ & Citrus latifolia & Mexico & MH271621 & MH286542 & MH279933 \\
\hline Lasiodiplodia iraniensis & CMM3610 & Jatropha curcas & Brazil & KF234544 & KF226690 & KF254927 \\
\hline Lasiodiplodia iraniensis & CMW36237 & Adansonia digitata & Mozambique & KU887121 & KU886998 & KU887499 \\
\hline Lasiodiplodia laeliocattleyae & BOT 29 & Mangifera indica & Egypt & JN814401 & JN814428 & N/A \\
\hline Lasiodiplodia laeliocattleyae & CBS130992 & Mangifera indica & Egypt & JN814397 & JN814424 & KU887508 \\
\hline Lasiodiplodia lignicola & CBS134112 & Deadwood & Thailand & JX646797 & KU887003 & JX646845 \\
\hline Lasiodiplodia macrospora & CMM3833 & Jatropha curcas & Brazil & KF234557 & KF226718 & KF254941 \\
\hline Lasiodiplodia mahajangana & CMW27818 & Terminalia catappa & Madagascar & FJ900596 & FJ900642 & FJ900631 \\
\hline Lasiodiplodia mahajangana & CMW27801 & Terminalia catappa & Madagascar & FJ900595 & FJ900641 & FJ900630 \\
\hline Lasiodiplodia margaritaceae & CBS122519 & Adansonia gibbosa & Australia & EU144050 & EU144065 & KU887520 \\
\hline Lasiodiplodia margaritaceae & CBS122065 & Adansonia gibbosa & Australia & EU144051 & EU144066 & N/A \\
\hline
\end{tabular}

${ }^{a}$ Newly deposited sequences are shown in bold. BL, personal number of B. T. Linaldeddu; BOT, A. M. Ismail, Plant Pathology Research Institute, Giza, Egypt; BT2, $\beta$-tubulin; CBS, Centraalbureau voor Schimmelcultures, Utrecht, The Netherlands; CGMCC, China General Microbiological Culture Collection, Beijing, China; CMM, Culture Collection of Phytopathogenic Fungi "Professora Maria Menezes," Universidade Federal Rural de Pernambuco, Recife, Brazil; CMW, Forestry and Agricultural Biotechnology Institute, University of Pretoria, Pretoria, South Africa; CPC, working collection of P. W. Crous housed at the CBS; N/A, sequence not available in GenBank; IBL, personal culture collection of I. B. L. Coutinho; IRAN, Culture Collection of the Iranian Research Institute of Plant Protection, Tehran, Iran; ITS, internal transcribed spacer; STE-U, Culture Collection of the Department of Plant Pathology, University of Stellenbosch, Stellenbosch, South Africa; TEF1, translation elongation factor 1- $\alpha$; UACH, Culture Collection of Phytopathogenic Fungi of Department of Agricultural Parasitology, Chapingo Autonomous University, Texcoco, Mexico; UCD, Phaff Yeast Culture Collection, Department of Food Science and Technology, University of California, Davis, U.S.A.; WAC, Department of Agriculture Western Australia Plant Pathogen Collection, Perth, Australia. 
The ITS region of ribosomal DNA was amplified using the primers ITS5/ITS4 (White et al. 1990). Parts of TEF1 and BT2 genes were amplified using the primers EF1-688F/EF1-1251R (Alves et al. 2008) and Bt2A/Bt2B (Glass and Donaldson 1995), respectively. The amplification conditions were as follows: an initial denaturation step at $94^{\circ} \mathrm{C}$ for $2 \mathrm{~min}$ followed by 35 cycles of denaturation at $94^{\circ} \mathrm{C}$ for $30 \mathrm{~s}$; annealing at $55^{\circ} \mathrm{C}$ for the ITS region, $54^{\circ} \mathrm{C}$ for the TEF1 gene, and $58^{\circ} \mathrm{C}$ for BT2 gene for $30 \mathrm{~s}$; extension at $72^{\circ} \mathrm{C}$ for $1 \mathrm{~min}$; and a final extension step at $72^{\circ} \mathrm{C}$ for $10 \mathrm{~min}$. The PCR assays were conducted in a Bio-Rad C1000 thermocycler (Bio-Rad Laboratories, Hercules, CA). The PCR products were separated by electrophoresis in $1 \%$ agarose gel stained with ethidium bromide and viewed under ultraviolet light. The amplified PCR products were purified using the QIAquick PCR Purification Kit (Qiagen, Valencia, CA) and sequenced by Macrogen (Macrogen Inc., Seoul, Korea) in both directions with the same primers that were used for the PCR reactions.

Phylogenetic analyses. Forward and reverse sequences were assembled using the Staden Package (Staden et al. 1998). Sequences

Table 1. (Continued from previous page)

\begin{tabular}{|c|c|c|c|c|c|c|}
\hline \multirow[b]{2}{*}{ Species } & \multirow[b]{2}{*}{ Isolate code } & \multirow[b]{2}{*}{ Host } & \multirow[b]{2}{*}{ Location } & \multicolumn{3}{|c|}{ GenBank accession number } \\
\hline & & & & ITS & TEF1 & BT2 \\
\hline Lasiodiplodia mediterranea & CBS137784 & Vitis vinifera & Italy & KJ638311 & KJ638330 & KU887522 \\
\hline Lasiodiplodia mediterranea & CBS137783 & Quercus ilex & Italy & KJ638312 & KJ638331 & KU887521 \\
\hline Lasiodiplodia missouriana & UCD2193MO & Vitis sp. & U.S.A. & HQ288225 & HQ288267 & HQ288304 \\
\hline Lasiodiplodia missouriana & UCD2199MO & Vitis sp. & U.S.A. & HQ288226 & HQ288268 & HQ288305 \\
\hline Lasiodiplodia parva & CBS494.78 & Cassava field soil & Colombia & EF622084 & EF622064 & EU673114 \\
\hline Lasiodiplodia parva & CBS456.78 & Cassava field soil & Colombia & EF622083 & EF622063 & KU887523 \\
\hline Lasiodiplodia plurivora & STE-U5803 & Prunus salicina & South Africa & EF445362 & EF445395 & KU887524 \\
\hline Lasiodiplodia plurivora & STE-U4583 & Vitis vinifera & South Africa & AY343482 & EF445396 & KU887525 \\
\hline Lasiodiplodia pontae & IBL12 & Spondias purpurea & Brazil & KT151794 & KT151791 & KT151797 \\
\hline Lasiodiplodia pseudotheobromae & CMM3887 & Jatropha curcas & Brazil & KF234559 & KF226722 & KF254943 \\
\hline Lasiodiplodia pseudotheobromae & CBS116459 & Gmelina arborea & Costa Rica & EF622077 & EF622057 & EU673111 \\
\hline Lasiodiplodia pseudotheobromae & $\mathrm{UACH} 258$ & Citrus latifolia & Mexico & MH277917 & MH286514 & MH279929 \\
\hline Lasiodiplodia pseudotheobromae & UACH259 & Citrus latifolia & Mexico & MH277926 & MH286522 & MH279919 \\
\hline Lasiodiplodia pseudotheobromae & $\mathrm{UACH} 260$ & Citrus latifolia & Mexico & MH277921 & MH286518 & MH279924 \\
\hline Lasiodiplodia pseudotheobromae & UACH261 & Citrus latifolia & Mexico & MH277919 & MH286516 & MH279926 \\
\hline Lasiodiplodia pseudotheobromae & UACH265 & Citrus latifolia & Mexico & MH277916 & MH286513 & MH279930 \\
\hline Lasiodiplodia pseudotheobromae & UACH271 & Citrus latifolia & Mexico & MH277920 & MH286517 & MH279925 \\
\hline Lasiodiplodia pseudotheobromae & $\mathrm{UACH} 274$ & Citrus latifolia & Mexico & MH277923 & MH286520 & MH279922 \\
\hline Lasiodiplodia pseudotheobromae & $\mathrm{UACH} 276$ & Citrus latifolia & Mexico & MH277915 & MH286512 & MH279931 \\
\hline Lasiodiplodia pseudotheobromae & UACH277 & Citrus latifolia & Mexico & MH277918 & MH286515 & MH279927 \\
\hline Lasiodiplodia pseudotheobromae & $\mathrm{UACH} 278$ & Citrus latifolia & Mexico & MH277927 & MH286524 & MH279918 \\
\hline Lasiodiplodia pseudotheobromae & $\mathrm{UACH} 279$ & Citrus latifolia & Mexico & MH277922 & MH286519 & MH279923 \\
\hline Lasiodiplodia pseudotheobromae & UACH281 & Citrus latifolia & Mexico & MH277924 & MH286521 & MH279921 \\
\hline Lasiodiplodia pseudotheobromae & $\mathrm{UACH} 283$ & Citrus latifolia & Mexico & MH277914 & MH286511 & MH279932 \\
\hline Lasiodiplodia pseudotheobromae & UACH286 & Citrus latifolia & Mexico & MH277925 & MH286523 & MH279920 \\
\hline Lasiodiplodia pseudotheobromae & UACH268 & Citrus latifolia & Mexico & MH277928 & MH286525 & MH279928 \\
\hline Lasiodiplodia pyriformis & CBS121771 & Acacia mellifera & Namibia & EU101308 & EU101353 & KU887528 \\
\hline Lasiodiplodia pyriformis & CBS121770 & Acacia mellifera & Namibia & EU101307 & EU101352 & KU887527 \\
\hline Lasiodiplodia rubropurpurea & CMW15207 & Eucalyptus grandis & Australia & DQ103554 & DQ103572 & KU887530 \\
\hline Lasiodiplodia rubropurpurea & CBS118740 & Eucalyptus grandis & Australia & DQ103553 & DQ103571 & EU673136 \\
\hline Lasiodiplodia thailandica & CPC22795 & Mangifera indica & Thailand & KJ193637 & KJ193681 & N/A \\
\hline Lasiodiplodia thailandica & CPC22755 & Phyllanthus acidus & Thailand & KJ193637 & KJ193681 & N/A \\
\hline Lasiodiplodia theobromae & CBS111530 & Unknown & Unknown & EF622074 & EF622054 & KU887531 \\
\hline Lasiodiplodia theobromae & CBS164.96 & Fruit along coral reef coast & New Guinea & AY640255 & AY640258 & KU887532 \\
\hline Lasiodiplodia theobromae & UACH263 & Citrus latifolia & Mexico & MH277691 & MH286528 & MH279908 \\
\hline Lasiodiplodia theobromae & $\mathrm{UACH} 264$ & Citrus latifolia & Mexico & МH277692 & MH286534 & MH279909 \\
\hline Lasiodiplodia theobromae & $\mathrm{UACH} 272$ & Citrus latifolia & Mexico & МH277693 & MH286533 & MH279915 \\
\hline Lasiodiplodia theobromae & UACH273 & Citrus latifolia & Mexico & MH277694 & MH286526 & MH279907 \\
\hline Lasiodiplodia theobromae & $\mathrm{UACH} 280$ & Citrus latifolia & Mexico & MH277695 & MH286527 & MH279910 \\
\hline Lasiodiplodia theobromae & $\mathrm{UACH} 284$ & Citrus latifolia & Mexico & MH277696 & MH286532 & MH279914 \\
\hline Lasiodiplodia theobromae & $\mathrm{UACH} 285$ & Citrus latifolia & Mexico & MH277697 & MH286531 & MH279913 \\
\hline Lasiodiplodia theobromae & $\mathrm{UACH} 287$ & Citrus latifolia & Mexico & MH277698 & MH286530 & MH279912 \\
\hline Lasiodiplodia theobromae & UACH288 & Citrus latifolia & Mexico & MH277699 & MH286529 & MH279911 \\
\hline Lasiodiplodia sterculiae & CBS342.78 & Sterculia oblonga & Germany & KX464140 & KX464634 & KX464908 \\
\hline Lasiodiplodia subglobosa & CMM4046 & Jatropha curcas & Brazil & KF234560 & KF226723 & KF254944 \\
\hline Lasiodiplodia subglobosa & CMM3872 & Jatropha curcas & Brazil & KF234558 & KF226721 & KF254942 \\
\hline Lasiodiplodia subglobosa & $\mathrm{UACH} 270$ & Citrus latifolia & Mexico & MH271619 & MH286539 & MH279916 \\
\hline Lasiodiplodia subglobosa & $\mathrm{UACH} 282$ & Citrus latifolia & Mexico & MH271620 & MH286540 & MH279917 \\
\hline Lasiodiplodia venezualensis & CBS118739 & Acacia mangium & Venezuela & DQ103547 & DQ103568 & KU887533 \\
\hline Lasiodiplodia venezuelensis & WAC12540 & Acacia mangium & Venezuela & DQ103548 & DQ103569 & KU887534 \\
\hline Lasiodiplodia viticola & UCD2604MO & Vitis sp. & U.S.A. & HQ288228 & HQ288270 & HQ288307 \\
\hline Lasiodiplodia viticola & UCD2553AR & Vitis sp. & U.S.A. & HQ288227 & HQ288269 & HQ288306 \\
\hline Lasiodiplodia vitis & CBS124060 & Vitis vinifera & Italy & KX464148 & KX464642 & KX464917 \\
\hline Neoscytalidium dimidiatum & CBS145.78 & Homo sapiens & United Kingdom & KF531816 & KF531795 & KF531796 \\
\hline
\end{tabular}


of the type and reference strains of Lasiodiplodia species of each locus analyzed were downloaded from GenBank and combined with the newly generated sequences (Table 1). Multiple sequence alignments for each locus independently were performed using the MEGA 7.0.14 (Kumar et al. 2016), and manual adjustments were done where necessary. Alignment of each locus was loaded in SequenceMatrix v.1.8 (Vaidya et al. 2011) to build the concatenated matrix.

The phylogeny for each locus (ITS, TEF1, and BT2) and the concatenated matrix were inferred under the Maximum Likelihood (ML) and Bayesian Inference (BI) criterion. The ML analyses were done in RAxML-HPC2 (Stamatakis 2014), and Bayesian phylogenetic estimates were done in MrBayes 3.2.6 (Ronquist et al. 2012) implemented on the CIPRES Science Gateway portal (https://www.phylo.org/portal2/home.action). The ML tree searches were performed under the GTRGAMMA model with 1,000 pseudoreplicates. The BI trees were constructed using the GTR + I + G (ITS), HKY + G (TEF1), and GTR + G (BT2) nucleotide substitution models, with four runs and four MCMC chains per run; Markov chains were run over 100,000,000 generations, and trees and parameter values were sampled every 10,000 generations. Sequences generated in this study were deposited in GenBank (Table 1), and the alignments and tree are in TreeBASE (http://purl.org/phylo/treebase/phylows/study/TB2:S23111).

Pathogenicity and virulence tests. Pathogenicity of 32 representative isolates was tested on healthy 18-month-old Persian lime plants obtained from a commercial nursery. For inoculation, branches of Persian lime plants were wounded using a sterile scalpel, and a colonized PDA plug (5-mm diameter) from a 6-day-old culture was placed on a wounded area. The inoculation site was sealed with parafilm to prevent desiccation. Four branches (two per plant) were inoculated with each isolate. Ten control branches were inoculated with noncolonized PDA plugs. Immediately after inoculation, each plant was covered with a plastic bag for $72 \mathrm{~h}$ to maintain humidity. All plants were maintained in a glasshouse under natural light conditions, and the temperature was regulated at $30{ }^{\circ} \mathrm{C} \pm 5^{\circ} \mathrm{C}$ by air conditioning. Virulence of isolates was assessed 30 days after inoculation by removing the bark and measuring the lesion length in the wood with a digital caliper. The experiment was conducted twice. Differences in virulence caused by Lasiodiplodia species were determined by one-way analysis of variance, and means were compared by LSD test at $\alpha=0.05$ using SAS (version 9.1; SAS Institute, Cary, NC).

\section{Results}

Field survey. Symptoms of gummosis, stem cankers, and dieback were detected in all surveyed orchards of Persian lime distributed in the states of Puebla and Veracruz. The highest incidence of disease was observed in the municipality of Hueytamalco with $97 \%$ followed by Martinez de la Torre with $96.5 \%$ and Acateno with $94.3 \%$. The lowest incidence rates were detected in Tlapacoyan and Papantla with 89 and $86 \%$, respectively.

Collection of samples and isolation. In this study, a total of 60 Lasiodiplodia isolates were obtained from Persian lime diseased tissues collected in 12 commercial orchards ( 5 isolates per orchard) distributed in the municipalities of Martinez de la Torre, Tlapacoyan, and Papantla in the state of Veracruz as well as in Acateno and Hueytamalco in the state of Puebla, Mexico. Based on colony morphology, a subsample of 32 representative isolates (at least two per orchard) was used for the phylogenetic analyses and pathogenicity tests.

Phylogenetic analyses. The isolates of Lasiodiplodia species were identified based on ML and BI phylogenetic analyses of the ITS region and parts of TEF1 and BT2 genes. The combined ITS, TEF1, and BT2 datasets consisted of 100 taxa, including 1 outgroup taxon. The alignment contained 1,309 characters, of which 348 corresponded with the TEF1 gene, 430 corresponded with the BT2 gene, and 531 corresponded with the ITS region. The combined datasets resulted in six well-supported clades corresponding to previously described Lasiodiplodia species (Fig.
2). The first clade with nine isolates (Culture Collection of Phytopathogenic Fungi of Department of Agricultural Parasitology, Chapingo Autonomous University, Texcoco, Mexico [UACH] 263, UACH264, UACH272, UACH273, UACH280, UACH284, UACH285, UACH287, and UACH288) clustered with Lasiodiplodia theobromae (Centraalbureau voor Schimmelcultures, Utrecht, The Netherlands [CBS] 111530 and CBS164.96), with $83 \%$ bootstrap support. The second clade with four isolates (UACH257, UACH266, UACH267, and UACH269) clustered with Lasiodiplodia brasiliense (Culture Collection of Phytopathogenic Fungi "Professora Maria Menezes," Universidade Federal Rural de Pernambuco, Recife, Brazil [CMM] 4015 and Forestry and Agricultural Biotechnology Institute, University of Pretoria, Pretoria, South Africa [CMW] 35884), with $86 \%$ bootstrap support. In the third clade, only one isolate (UACH275) clustered with Lasiodiplodia iraniensis (CMM3610 and CMW36237), with $100 \%$ bootstrap support. The fourth clade with two isolates (UACH270 and UACH282) clustered with Lasiodiplodia subglobosa (CMM3872 and CMM4046), with 97\% bootstrap support. The fifth clade had the highest number of isolates (UACH258, UACH259, UACH260, UACH261, UACH265, UACH268, UACH271, UACH274, UACH276, UACH277, UACH278, UACH279, UACH281, UACH283, and UACH286), which clustered with Lasiodiplodia pseudotheobromae (CBS116459 and CMM3887), with $85 \%$ bootstrap support. The sixth clade has only one isolate (UACH262) clustered with Lasiodiplodia citricola (CBS124707 and Culture Collection of the Iranian Research Institute of Plant Protection, Tehran, Iran 1521C), with 100\% bootstrap support (Fig. 2).

Distribution of Lasiodiplodia species. L. pseudotheobromae was the most frequently isolated species $(46.9 \%)$ from Persian lime trees followed by L. theobromae (28.1\%), L. brasiliense (12.5\%), L. subglobosa $(6.3 \%)$, L. iraniensis (3.1\%), and L. citricola (3.1\%). The distribution of Lasiodiplodia species varied among the five populations distributed in the states of Puebla and Veracruz, Mexico (Fig. 3). L. pseudotheobromae was found in all populations. $L$. theobromae and L. subglobosa were found in at least one population of each state. L. brasiliense was recorded only in the two populations from the state of Puebla. L. iraniensis was identified only in the Papantla population. L. citricola was only isolated from an orchard located in Acateno, Puebla.

Pathogenicity and virulence on branches. Thirty days after inoculation, all isolates belonging to the six species of Lasiodiplodia identified in this study were pathogenic on Persian lime young plants using a mycelial plug inoculation method. The symptoms produced on the wood were necrotic lesions that extended upward and downward from the inoculation site (Fig. 4). All isolates of Lasiodiplodia induced the formation of gum exudations on the branches (Fig. 4), whereas no disease symptoms were observed on the control plants. Lasiodiplodia isolates were consistently recovered from the diseased branches, whereas no Lasiodiplodia spp. were isolated from healthy control plants, thus fulfilling Koch's postulates. The two experiments did not differ significantly $(P=0.05)$; thus, the data from both experiments were combined for statistical analyses. The mean lesion lengths caused by species of Lasiodiplodia for the combination of two experiments are shown in Fig. 5.

There were significant differences $(P=0.001)$ in internal necrosis length produced by the different Lasiodiplodia species. The longest mean lesions (>19 mm) were produced by L. subglobosa, L. iraniensis, and L. pseudotheobromae, which were the most virulent species. In addition, these species caused longitudinal cracks on the bark of the branches. However, the shorter mean lesions $(<14 \mathrm{~mm})$ were induced by $L$. theobromae, L. brasiliense, and L. citricola, which were considered the least virulent species.

\section{Discussion}

This study showed the first findings about Lasiodiplodia species infecting Persian lime trees in Mexico. Six Lasiodiplodia species were isolated from stem cankers and dieback of branches, and they 
were identified based on phylogenetic analyses of combined ITS, BT2, and TEF1 sequence datasets. These species included L. pseudotheobromae, L. theobromae, L. brasiliense, L. subglobosa, L. citricola, and $L$. iraniensis. All Lasiodiplodia species of this study are reported for the first time in association with Persian lime in Mexico and worldwide. A detailed morphological characterization of
Lasiodiplodia isolates was not performed, because the identification of Botryosphaeriaceae species using morphology is virtually impossible, and it should be only used to distinguish between genera and complement the DNA phylogeny for the description of new species (Ismail et al. 2012; Osorio et al. 2017; Phillips et al. 2013; Slippers et al. 2014). The most appropriate way to differentiate species within

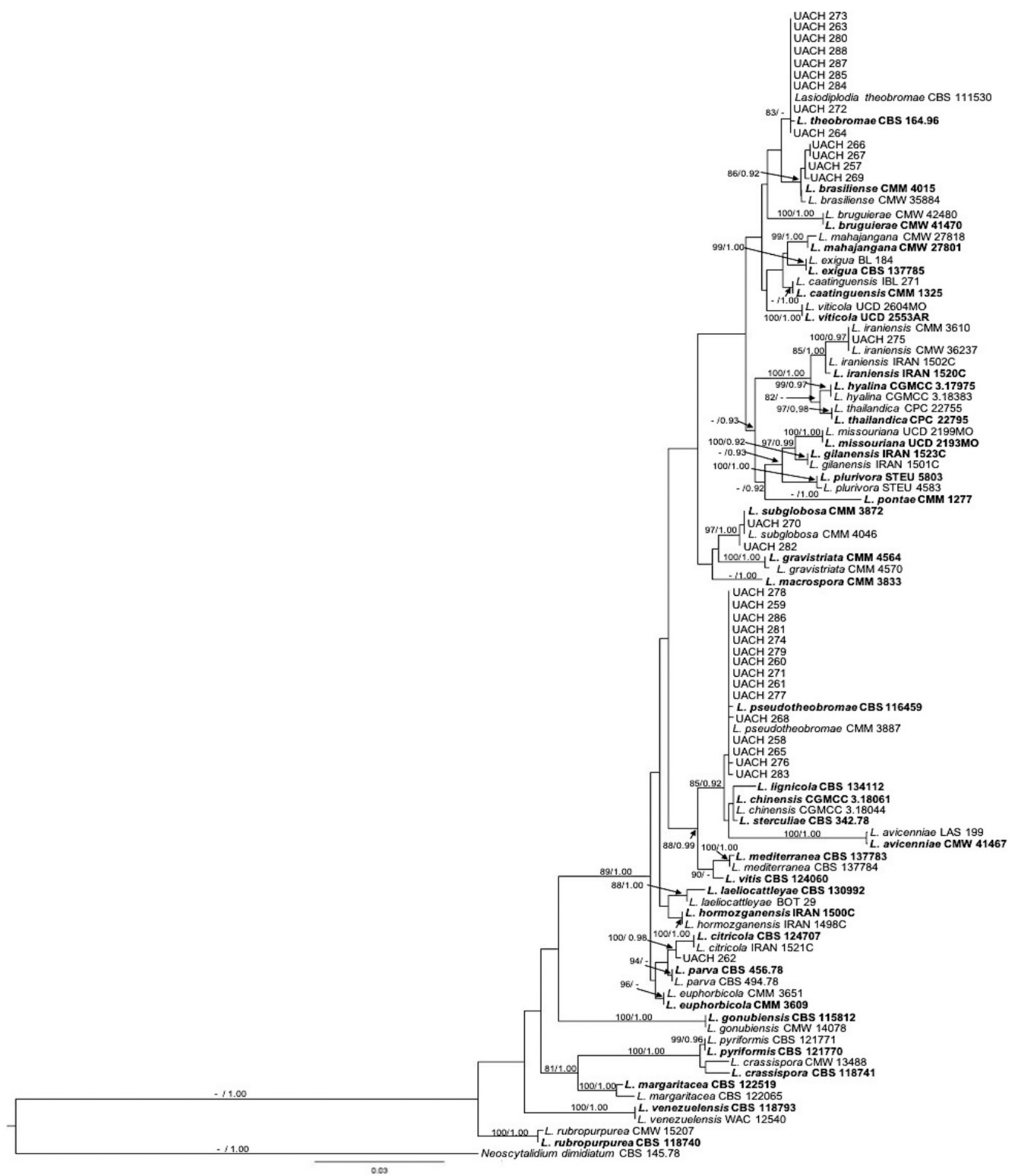

Fig. 2. Phylogenetic tree of Lasiodiplodia species inferred from a concatenated alignment of an internal transcribed spacer, $\beta$-tubulin, and translation elongation factor 1 - $\alpha$ sequence alignments. Bootstrap values by the Maximum Likelihood method and probabilities by the Bayesian Inference analyses are shown on the respective branches. Bootstrap values below $80 \%$ and posterior probabilities below 0.90 are not shown. The tree is rooted to Neoscytalidium dimidiatum CBS 145.78. Epi- and ex-type strains are indicated in bold. The scale bar indicates the average number of substitutions per site. 


\begin{tabular}{|c|c|}
\hline & L. pseudotheobromae \\
\hline & L. theobromae \\
\hline 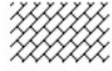 & L. brasiliense \\
\hline WIIII, & L. subglobosa \\
\hline :4:4;: & L. citricola \\
\hline 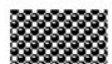 & L. iraniensis \\
\hline
\end{tabular}

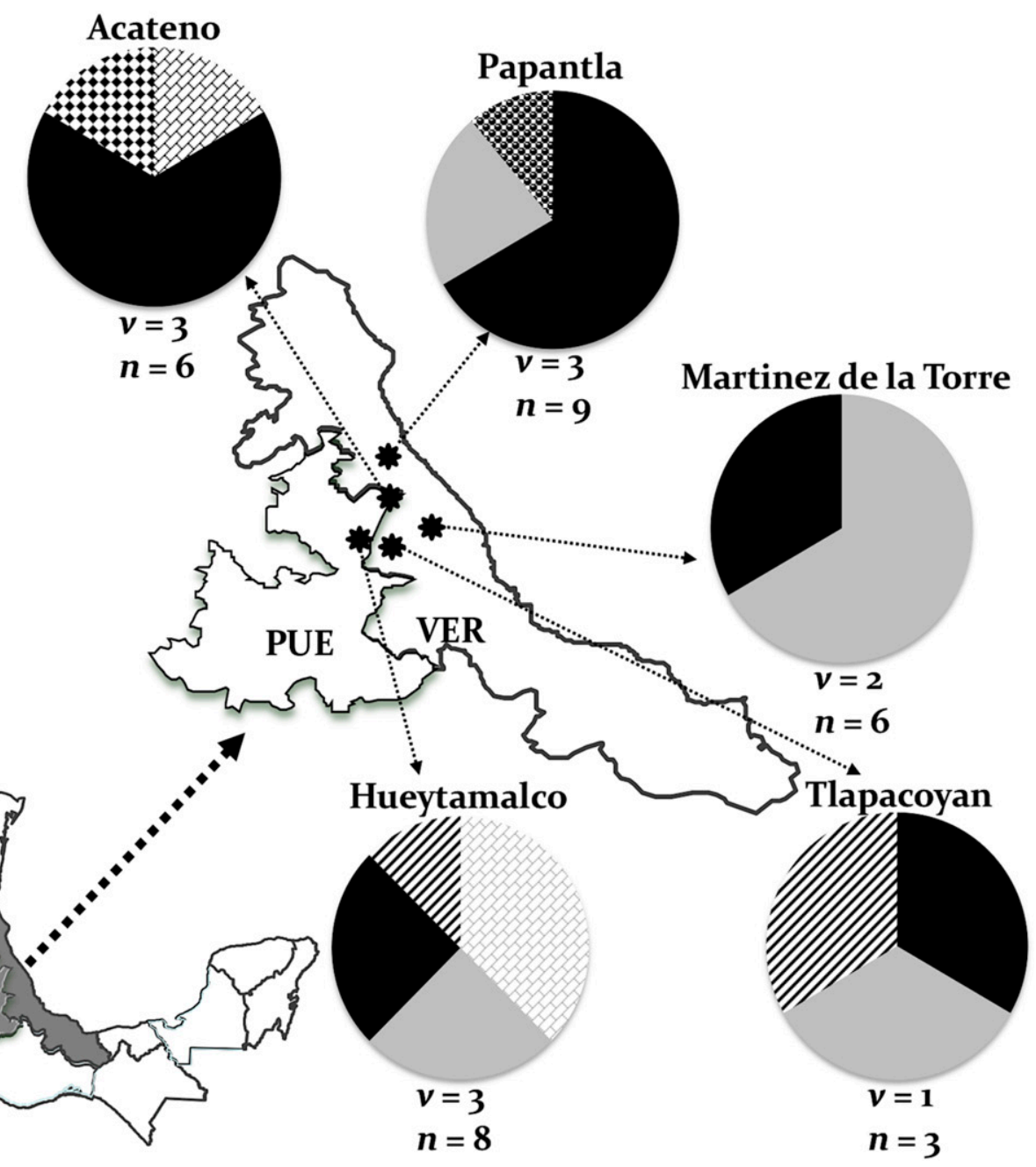

Fig. 3. Collection sites of six Lasiodiplodia spp. associated with Persian lime (Citrus latifolia) dieback in five populations distributed in the states of Puebla (PUE) and Veracruz (VER), Mexico. Circles represent association frequency of each species with Persian lime trees showing symptoms of dieback in each population sampled, $v$ is the number of commercial orchards sampled in each population, and $n$ is the number of isolates analyzed in each population. L. brasiliense, Lasiodiplodia brasiliense; $L$. citricola, Lasiodiplodia citricola; L. iraniensis, Lasiodiplodia iraniensis; L. pseudotheobromae, Lasiodiplodia pseudotheobromae; L. subglobosa, Lasiodiplodia subglobosa; L. theobromae, Lasiodiplodia theobromae.
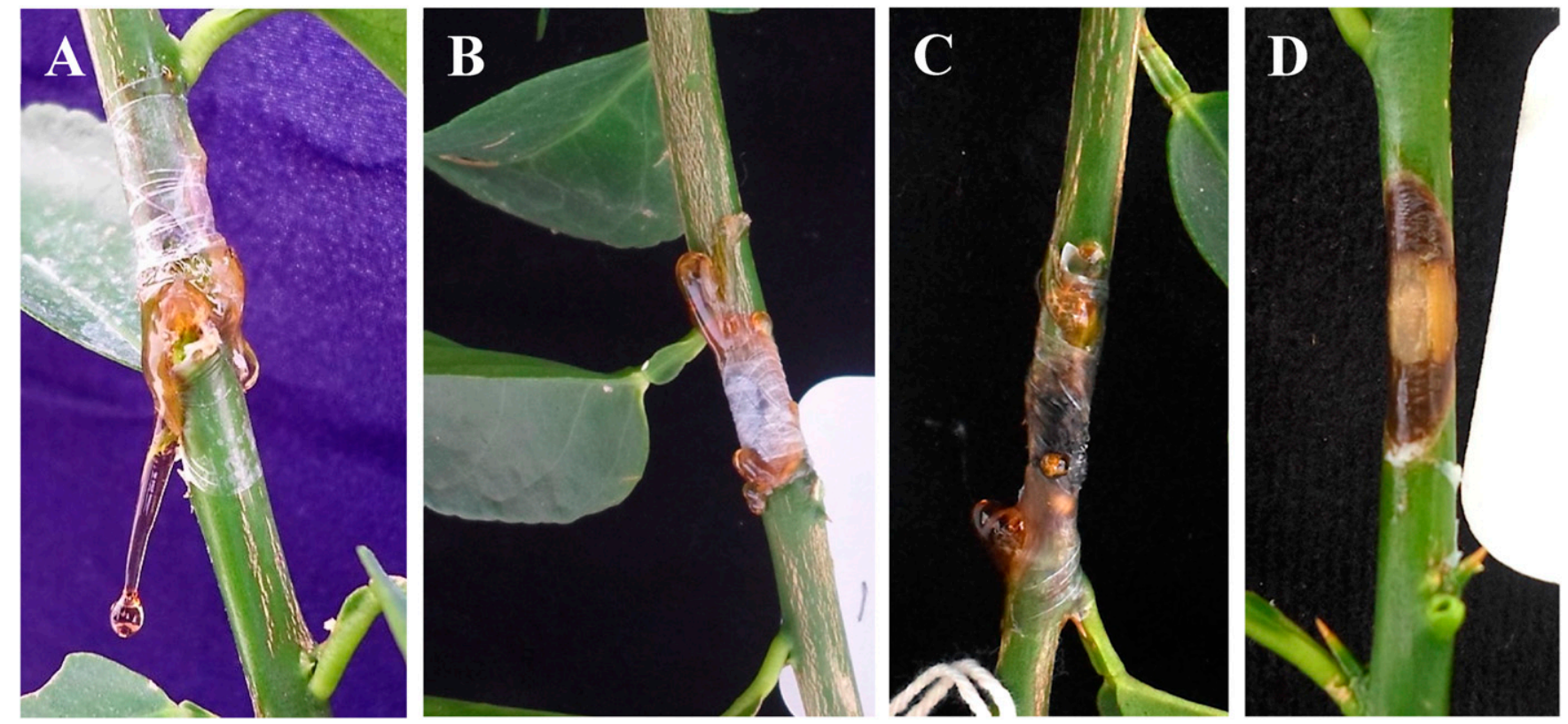

Fig. 4. Symptoms developed in the branches of young Persian lime (Citrus latifolia) plants artificially inoculated with Lasiodiplodia spp. 30 days after inoculation. A and B, Branches producing gum exudations. C, Symptomatic branch with necrosis and gummosis. D, Branch with necrosis around inoculation site. 
Botryosphaeriaceae is through of DNA sequence data, preferably combining sequences from multiple loci (Dissanayake et al. 2016; Phillips et al. 2013; Rodríguez-Gálvez et al. 2017; Slippers et al. 2014).

L. pseudotheobromae was the most frequently isolated species from Persian lime plants with dieback symptoms, and it occurred in the five populations analyzed in this study. This fungal species has been previously associated with diseases on some citrus species, including sour orange in Suriname (Alves et al. 2008), Citrus species in Iran (Abdollahzadeh et al. 2010), and lemon in Turkey (Awan et al. 2016). Similarly, this fungus has been commonly isolated from mango (Mangifera indica L.) tissues with symptoms of dieback and/or stem end rot worldwide (Ismail et al. 2012; Marques et al. 2013; Munirah et al. 2017; Rodríguez-Gálvez et al. 2017; Sakalidis et al. 2011; Trakunyingcharoen et al. 2014; 2015). In addition, it has been recorded in Brazil on fruit trees, including cashew (Anacardium occidentale L.) (Coutinho et al. 2017; Netto et al. 2017), hog plum (Spondias purpurea L.), and Tamarindus indica L. (Coutinho et al. 2017). Results of pathogenicity tests revealed that isolates of $L$. pseudotheobromae were more virulent in Persian lime branches than $L$. theobromae isolates. These results agree with those reported by Begoude et al. $(2010,2011)$ and Chen et al. (2011), who found that L. pseudotheobromae was more virulent than L. theobromae when inoculated on stems of tropical almond (Terminalia catappa), Eucalyptus spp., and Terminalia spp. In contrast to our results, Correia et al. (2016), Marques et al. (2013), and Netto et al. (2017) determined that $L$. theobromae isolates were more virulent than L. pseudotheobromae isolates when inoculated on mango fruits, detached green shoots of grapes, and detached green shoots of cashew.

L. theobromae was the second most abundant species isolated from Persian lime orchards in Mexico. This species has a cosmopolitan distribution, particularly in tropical and subtropical regions, where it causes a variety of diseases on a wide range of host plants (Punithalingam 1980). Studies based on the combination of morphological characters and DNA sequence data confirmed that this fungus is a common pathogen in fruit crops of economic importance, such as mango (Abdollahzadeh et al. 2010; Al-Jabri et al. 2017; Al-Sadi et al. 2013; de Oliveira Costa et al. 2010; Ismail et al. 2012; Marques et al. 2013; Munirah et al. 2017; Ni et al. 2012; Rodríguez-Gálvez et al. 2017; Sakalidis et al. 2011; Trakunyingcharoen et al. 2014), papaya (Carica papaya L.) (Netto et al. 2014), coconut palm (Cocos nucifera L.) (Rosado et al. 2016), kiwifruit (Actinidia chinensis Planch.) (Zhou et al. 2015), Vitis spp. (Correia et al. 2016; Rodríguez-Gálvez et al. 2015), cashew (Coutinho et al. 2017; Netto et al. 2017), hog plum, and Talisia esculenta (Coutinho et al. 2017). Similarly, L. theobromae has been recorded as the second most frequently isolated species after L. pseudotheobromae in symptomatic tissues of the ornamental tree known as tropical almond in Madagascar and South Africa (Begoude et al. 2010). Regarding citrus species, Davis et al. (1987) recorded a trunk disease of young citrus trees caused by two isolates of L. theobromae in Texas, U.S.A. and also showed that some isolates were apparently avirulent. This pathogen also has been associated with dieback and gummosis symptoms on acid lime, sweet orange, and sweet lime in Oman (Al-Sadi et al. 2013) and lemon in Venezuela (Ferrari et al. 1996) and Chile (Guajardo et al. 2018). In Mexico, L. theobromae was previously associated as the causal agent of bot canker disease of grapevines based on morphological and cultural characters as well as analyses of ITS, BT2, and TEF1 sequences (Úrbez-Torres et al. 2008). Subsequently, other studies have mentioned the occurrence of $L$. theobromae as a common pathogen on fruit crops in Mexico, including Pouteria sapota (Vásquez-López et al. 2009), mango (Sandoval-Sánchez et al. 2013), and physic nut (Uc-Várguez et al. 2017). However, all of these isolates were identified based on morphological characteristics and analysis of the ITS region, and therefore, it is necessary to verify and update the inventory of Botryosphaeriaceae species associated with the main fruit crops in Mexico by analysis of sequences of at least three genes. In this study, L. theobromae was less virulent than $L$. pseudotheobromae in inoculated young plants of Persian lime.
This finding contrasts with that found by Marques et al. (2013), who determined that $L$. theobromae was more virulent than L. pseudotheobromae in inoculated mango fruits. In the case of citrus, AlSadi et al. (2014) found that $L$. theobromae was more virulent than Lasiodiplodia hormozganensis on inoculated twigs of acid lime and sweet lime, because L. hormozganensis induced symptoms of gummosis and dieback, similar to those induced by $L$. theobromae observed in our study.

L. brasiliense was the third most common species of all of the isolates examined in our study. This species was previously reported to be a pathogen of mango (Coutinho et al. 2017; Netto et al. 2014; Rodríguez-Gálvez et al. 2017), papaya (Netto et al. 2014), coconut palm (Rosado et al. 2016), table grapes (Correia et al. 2016), sapodilla (Manilkara zapota L.), hog plum (Coutinho et al. 2017), cashew (Netto et al. 2017), custard apple (Annona squamosa L.) (Cardoso et al. 2017), and apple (Martins et al. 2018) in Brazil. In addition, this fungus was recorded on Tectona grandis in Thailand (Doilom et al. 2015) and Eucalyptus hybrid (Li et al. 2018) and mango (Zhang et al. 2018) in China. Thus, this study represents the first report of this fungus on a citrus worldwide. In 2017, Cruywagen et al. (2017) considered $L$. brasiliense as a hybrid that could have arisen from hybridization between $L$. theobromae and another currently unknown species; however, additional studies are needed to confirm this hybrid status. In our study, L. brasiliense and L. theobromae exhibited low levels of virulence, whereas L. pseudotheobromae was highly virulent in Persian lime young plants. A recent study by Netto et al. (2014) showed that L. brasiliense, L. theobromae, and $L$. pseudotheobromae did not differ with respect to their virulence in papaya fruits. In contrast to our results, Correia et al. (2016) found that $L$. brasiliense and $L$. theobromae were highly virulent species, and L. pseudotheobromae exhibited an intermediate virulence in detached green shoots of grapes. Rosado et al. (2016) observed that $L$. theobromae was highly virulent in coconut fruits compared with $L$. brasiliense and $L$. pseudotheobromae. Subsequently, Netto et al. (2017) noted that L. brasiliense and L. theobromae exhibited intermediate virulence, and L. pseudotheobromae presented a low level of virulence in detached green shoots of cashew. All of the studies mentioned above show a wide range of virulence of $L$. brasiliense isolates in different tissues of fruit crop hosts.

L. subglobosa was described from physic nut collected in Brazil (Machado et al. 2014), and later, it was reported by Poletto et al. (2016) to be causing stem canker of pecan (Carya illinoinensis [Wangenh.] Koch). Thus, this study represents the first report of

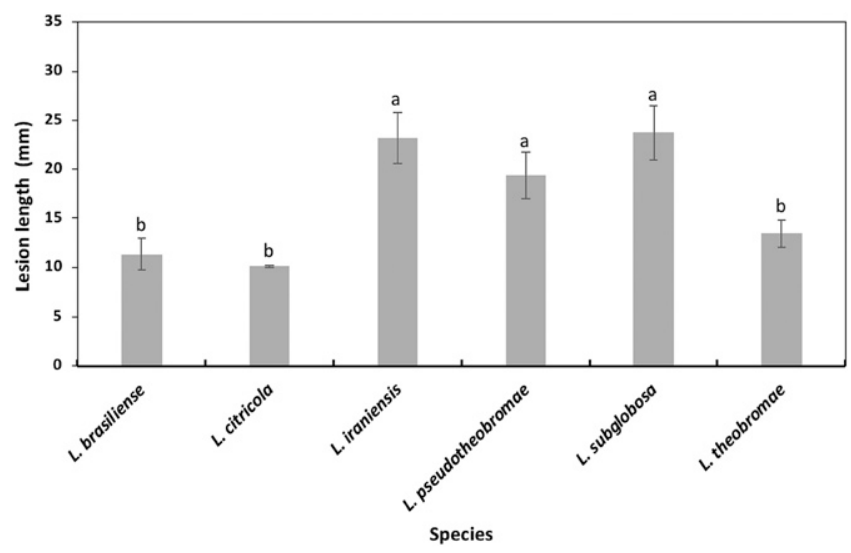

Fig. 5. Virulence of six Lasiodiplodia species associated with dieback of Persian lime (Citrus latifolia) as measured by mean internal lesion lengths (millimeters). Data are lesion sizes measured 30 days after inoculation with mycelium-colonized agar plugs inserted into wounded branches of young lime trees. Bars above columns are the standard errors of the means. Columns with the same letter do not differ significantly according to Fisher's LSD test $(P \leq 0.05)$. L. brasiliense, Lasiodiplodia brasiliense; L. citricola, Lasiodiplodia citricola; L. iraniensis, Lasiodiplodia iraniensis; L. pseudotheobromae, Lasiodiplodia pseudotheobromae; L. subglobosa, Lasiodiplodia subglobosa; L. theobromae, Lasiodiplodia theobromae. 
this species in Mexico and from outside Brazil. Results of pathogenicity tests showed that $L$. subglobosa was the most virulent species in young Persian lime plants, although it was not the most common species.

L. citricola and $L$. iraniensis were less common species and occurred at the same frequency among the isolates obtained from symptomatic Persian lime tissues in Mexico. L. citricola was first introduced by Abdollahzadeh et al. (2010) for isolates from Citrus species in Iran and later associated with other species causing canker in peach trees (Prunus persica L.) (Chen et al. 2013) as well as being fungal species responsible for inducing various symptoms in tissues of English walnut (Juglans regia L.) (Chen et al. 2014a) and pistachio (Pistacia vera L.) (Chen et al. 2014b) in California, U.S.A.. In Italy, L. citricola was associated as causal agent of trunk disease on grapevines (Carlucci et al. 2015). However, Rodríguez-Gálvez et al. (2017) suggested two hypotheses regarding this species. The first hypothesis suggests that there are hybrids isolates between $L$. citricola and Lasiodiplodia parva, and the second hypothesis suggest that $L$. citricola and $L$. parva represent a single species, with the small differences between them being a representation of the intraspecific genetic variability. Either hypothesis can be confirmed in additional studies.

L. iraniensis was first described from diseased plants of Salvadora persica, Juglans sp., mango, Eucalyptus sp., Citrus sp., and tropical almond collected in Iran (Abdollahzadeh et al. 2010); later, this pathogen was associated with mandarin (Al-Sadi et al. 2013), mango (AlSadi et al. 2013; Marques et al. 2013; Rodríguez-Gálvez et al. 2017; Sakalidis et al. 2011), Bougainvillea spectabilis (Li et al. 2015), and Anacardium occidentale (Netto et al. 2017). According to Netto et al. (2017), Lasiodiplodia jatrophicola is phylogenetically closely related yet clearly distinct from $L$. iraniensis, with larger conidia and shorter paraphyses typical of this species. However, Cruywagen et al. (2017) and Rodríguez-Gálvez et al. (2017) indicated that $L$. jatrophicola and L. iraniensis should be considered as synonyms, because the two species cannot be separated based solely on DNA sequence phylogeny using combined data of ITS and TEF1 sequences. Additional studies are required with a large number of isolates of both species as well as analysis of additional gene sequence data to resolve these uncertainties as indicated by Yang et al. (2017).

Overall, the results from this research showed great similarity to the results from studies performed by Correia et al. (2016), Machado et al. (2014), and Netto et al. (2017) in Brazil, because they identified at least three of the same Lasiodiplodia species reported on Persian lime trees in Mexico. These phylogenetic studies have shown the great diversity of Lasiodiplodia species associated with diseases in crops of economic importance in both countries. Therefore, it is necessary to explore this diversity in detail through subsequent studies.

Although we identified six Lasiodiplodia species associated with Persian lime in Mexico, we did not find some species, such as Lasiodiplodia hormozganensis (Al-Sadi et al. 2013), L. parva (Adesemoye et al. 2014), Lasiodiplodia mediterranea (Linaldeddu et al. 2015), and Lasiodiplodia caatinguensis (Coutinho et al. 2017), which have been previously reported on other citrus species worldwide. Our results add to a growing body of data and confirm that there are at least 10 Lasiodiplodia species that are able to cause diseases in Citrus spp. worldwide.

In conclusion, the findings of this study represent the first detailed research about the phylogeny, distribution, and pathogenicity of six Lasiodiplodia species associated with gummosis and dieback symptoms of Persian lime trees in the central coastal region of the Gulf of Mexico and worldwide. Although L. pseudotheobromae and L. theobromae were the most frequently isolated species, all Lasiodiplodia species proved to be pathogenic to young Persian lime plants, with L. subglobosa, L. iraniensis, and L. pseudotheobromae being the most virulent. This complex of Lasiodiplodia species is a threat to the Persian lime industry, and additional studies on the impact, biology, fungicide sensitivity, and epidemiology of these fungi are needed for the development of suitable management strategies to reduce the disease impact on the productivity and longevity of Persian lime orchards in Mexico.

\section{Literature Cited}

Abdollahzadeh, J., Javadi, A., Goltapeh, E. M., Zare, R., and Phillips, A. J. L. 2010. Phylogeny and morphology of four new species of Lasiodiplodia from Iran. Persoonia 25:1-10.

Adesemoye, A. O., Mayorquin, J. S., Wang, D. H., Twizeyimana, M., Lynch, S. C., and Eskalen, A. 2014. Identification of species of Botryosphaeriaceae causing bot gummosis in citrus in California. Plant Dis. 98:55-61.

Al-Jabri, M. K., Al-Shaili, M., Al-Hashmi, M., Nasehi, A., Al-Mahmooli, I. H., and Al-Sadi, A. M. 2017. Characterization and evaluation of fungicide resistance among Lasiodiplodia theobromae isolates associated with mango dieback in Oman. J. Plant Pathol. 99:753-759.

Al-Sadi, A. M., Al-Ghaithi, A. G., Al-Fahdi, N., and Al-Yahyai, R. 2014. Characterization and pathogenicity of fungal pathogens associated with root diseases of Citrus in Oman. Int. J. Agric. Biol. 16:371-376.

Al-Sadi, A. M., Al-Wehaibi, A. N., Al-Shariqi, R. M., Al-Hammadi, M. S., AlHosni, I. A., Al-Mahmooli, I. H., and Al-Ghaithi, A. G. 2013. Population genetic analysis reveals diversity in Lasiodiplodia species infecting date palm, Citrus, and mango in Oman and the UAE. Plant Dis. 97:1363-1369.

Alves, A., Crous, P. W., Correia, A., and Phillips, A. J. L. 2008. Morphological and molecular data reveal cryptic speciation in Lasiodiplodia theobromae. Fungal Divers. 28:1-13.

Awan, Q. N., Akgül, D. S., and Unal, G. 2016. First report of Lasiodiplodia pseudotheobromae causing postharvest fruit rot of lemon in Turkey. Plant Dis. 100:2327.

Begoude, B. A. D., Slippers, B., Wingfield, M. J., and Roux, J. 2010. Botryosphaeriaceae associated with Terminalia catappa in Cameroon, South Africa and Madagascar. Mycol. Prog. 9:101-123.

Begoude, B. A. D., Slippers, B., Wingfield, M. J., and Roux, J. 2011. The pathogenic potential of endophytic Botryosphaeriaceous fungi on Terminalia species in Cameroon. For. Pathol. 41:281-292.

Cardoso, J. E., Lima, J. S., Viana, F. M. P., Ootani, M. A., Araújo, F. S. A., Fonseca, W. L., Lima, C. S., and Martins, M. V. V. 2017. First report of Lasiodiplodia brasiliense causing postharvest fruit rot of custard apple (Annona squamosa) in Brazil. Plant Dis. 101:1542.

Carlucci, A., Cibelli, F., Lops, F., and Raimondo, M. L. 2015. Characterization of Botryosphaeriaceae species as causal agents of trunk disease on grapevines. Plant Dis. 99:1678-1688.

Chen, S. F., Morgan, D. P., Hasey, J. K., Anderson, K., and Michailides, T. J. 2014a. Phylogeny, morphology, distribution, and pathogenicity of Botryosphaeriaceae and Diaporthaceae from English walnut in California. Plant Dis. 98:636-652.

Chen, S. F., Morgan, D. P., Hasey, J. K., and Michailides, T. J. 2013. First report of Lasiodiplodia citricola associated with stem canker of peach in California, USA. J. Plant Pathol. 95:659.

Chen, S. F., Morgan, D. P., and Michailides, T. J. 2014b. Botryosphaeriaceae and Diaporthaceae associated with panicle and shoot blight of pistachio in California, USA. Fungal Divers. 67:157-179.

Chen, S. F., Pavlic, D., Roux, J., Slippers, B., Xie, Y. J., Wingfield, M. J., and Zhou, X. D. 2011. Characterization of Botryosphaeriaceae from plantationgrown Eucalyptus species in South China. Plant Pathol. 60:739-751.

Correia, K. C., Silva, M. A., de Morais, M. A., Jr., Armengol, J., Phillips, A. J. L., Câmara, M. P. S., and Michereff, S. J. 2016. Phylogeny, distribution and pathogenicity of Lasiodiplodia species associated with dieback of table grape in the main Brazilian exporting region. Plant Pathol. 65:92-103.

Coutinho, I. B. L., Freire, F. C. O., Lima, C. S., Lima, J. S., Gonçalves, F. J. T., Machado, A. R., Silva, A. M. S., and Cardoso, J. E. 2017. Diversity of genus Lasiodiplodia associated with perennial tropical fruit plants in northeastern Brazil. Plant Pathol. 66:90-104.

Cruywagen, E. M., Slippers, B., Roux, J., and Wingfield, M. J. 2017. Phylogenetic species recognition and hybridization in Lasiodiplodia: A case study on species from baobabs. Fungal Biol. 121:420-436.

Davis, R. M., Farrald, C. J., and Davila, D. 1987. Botryodiplodia trunk lesions in Texas citrus. Plant Dis. 71:848-849.

de Oliveira Costa, V. S., Michereff, S. J., Martins, R. B., Gava, C. A. T., Mizubuti, E. S. G., and Câmara, M. P. S. 2010. Species of Botryosphaeriaceae associated on mango in Brazil. Eur. J. Plant Pathol. 127:509-519.

Dissanayake, A. J., Phillips, A. J. L., Li, X. H., and Hyde, K. D. 2016. Botryosphaeriaceae: Current status of genera and species. Mycosphere 7:1001-1073.

Doilom, M., Shuttleworth, L. A., Roux, J., Chukeatirote, E., and Hyde, K. D. 2015. Botryosphaeriaceae associated with Tectona grandis (teak) in Northern Thailand. Phytotaxa 233:1-26.

Ferrari, F. D., Ochoa, C. F. M., and Subero, M. L. J. 1996. Dieback and gummosis induced by Lasiodiplodia theobromae (Pat.) Griffon and Maubl. on three citrus tree species. Anal. Bot. Agric. 3:46-49.

Food and Agriculture Organization (FAO). 2016. Agricultural Production Index. http://www.fao.org/faostat/en/.

Glass, N. L., and Donaldson, G. C. 1995. Development of primer sets designed for use with the PCR to amplify conserved genes from filamentous ascomycetes. Appl. Environ. Microbiol. 61:1323-1330.

Guajardo, J., Riquelme, N., Tapia, L., Larach, A., Torres, C., Camps, R., and Besoain, X. 2018. First report of Lasiodiplodia theobromae causing bot gummosis in Citrus limon in Chile. Plant Dis. 102:818. 
Ismail, A. M., Cirvilleri, G., Polizzi, G., Crous, P. W., Groenewald, J. Z., and Lombard, L. 2012. Lasiodiplodia species associated with dieback disease of mango (Mangifera indica) in Egypt. Australas. Plant Pathol. 41:649-660.

Kumar, S., Stecher, G., and Tamura, K. 2016. MEGA7: Molecular Evolutionary Genetics Analysis version 7.0 for bigger datasets. Mol. Biol. Evol. 33:1870-1874.

Li, G. Q., Arnold, R. J., Liu, F. F., Li, J. Q., and Chen, S. F. 2015. Identification and pathogenicity of Lasiodiplodia species from Eucalyptus urophylla $\mathrm{x}$ grandis, Polyscias balfouriana and Bougainvillea spectabilis in Southern China. J. Phytopathol. 163:956-967.

Li, G. Q., Liu, F. F., Li, J. Q., Liu, Q. L., and Chen, S. F. 2018. Botryosphaeriaceae from Eucalyptus plantations and adjacent plants in China. Persoonia 40:63-95.

Linaldeddu, B. T., Deidda, A., Scanu, B., Franceschini, A., Serra, S., BerrafTebbal, A., Zouaoui Boutiti, M., Ben Jamaa, M. L., and Philips, A. J. L. 2015. Diversity of Botryosphaeriaceae species associated with grapevine and other woody hosts in Italy, Algeria and Tunisia, with descriptions of Lasiodiplodia exigua and Lasiodiplodia mediterranea sp. nov. Fungal Divers. 71:201-214.

Machado, A. R., Pinho, D. B., and Pereira, O. L. 2014. Phylogeny, identification and pathogenicity of the Botryosphaeriaceae associated with collar and root rot of the biofuel plant Jatropha curcas in Brazil, with a description of new species of Lasiodiplodia. Fungal Divers. 67:231-247.

Marques, M. W., Lima, N. B., Morais, M. A., Jr., Barbosa, M. A. G., Souza, B. O., Michereff, S. J., Phillips, A. J. L., and Câmara, M. P. S. 2013. Species of Lasiodiplodia associated with mango in Brazil. Fungal Divers. 61:181-193.

Martins, M. V. V., Lima, J. S., Hawerroth, F., Ootani, M. A., Araújo, F. S. A., Cardoso, J. E., Serrano, L., and Viana, F. M. 2018. First report of Lasiodiplodia brasiliensis causing disease in apple trees in Brazil. Plant Dis. 102:1027.

Mayorquin, J. S., Wang, D. H., Twizeyimana, M., and Eskalen, A. 2016. Identification, distribution, and pathogenicity of Diatrypaceae and Botryosphaeriaceae associated with citrus branch canker in the southern California desert. Plant Dis. 100: 2402-2413.

Mendoza-Tornez, R., Marquez-Berber, S. R., Almaguer-Vargas, G., AguilarAvila, J., Gardezi, A. K., and Ayala-Garay, A. V. 2016. Value network of the Persian lime in Mexico. AGROFOR Inter. J. 1:39-45.

Munirah, M. S., Azmi, A. R., Yong, S. Y. C., and Nur-Ain-Izzati, M. Z. 2017. Characterization of Lasiodiplodia theobromae and L. pseudotheobromae causing fruit rot on pre-harvest mango in Malaysia. Plant Pathol. Quar. 7: 202-213.

Netto, M. S. B., Assunção, I. P., Lima, G. S. A., Marques, M. W., Lima, W. G., Monteiro, J. H. A., Balbino, V. Q., Michereff, S. J., Phillips, A. J. L., and Câmara, M. P. S. 2014. Species of Lasiodiplodia associated with papaya stem-end rot in Brazil. Fungal Divers. 67:127-141.

Netto, M. S. B., Lima, W. G., Correia, K. C., Da Silva, C. F. B., Thon, M., Martins, R. B., Miller, R. N. G., Michereff, S. J., and Câmara, M. P. S. 2017. Analysis of phylogeny, distribution, and pathogenicity of Botryosphaeriaceae species associated with gummosis of Anacardium in Brazil, with a new species of Lasiodiplodia. Fungal Biol. 121:437-451.

Ni, H. F., Yang, H. R., Chen, R. S., Liou, R. F., and Hung, T. H. 2012. New Botryosphaeriaceae fruit rot of mango in Taiwan: Identification and pathogenicity. Bot. Stud. (Taipei, Taiwan) 53:467-478.

Osorio, J. A., Crous, C. J., de Beer, Z. W., Wingfield, M. J., and Roux, J. 2017. Endophytic Botryosphaeriaceae, including five new species, associated with mangrove trees in South Africa. Fungal Biol. 121:361-393.

Phillips, A. J. L., Alves, A., Abdollahzadeh, J., Slippers, B., Wingfield, M. J., Groenewald, J. Z., and Crous, P. W. 2013. The Botryosphaeriaceae: Genera and species known from culture. Stud. Mycol. 76:51-167.

Poletto, T., Gonzatto, M. C., Muniz, M., Blume, E., Poletto, I., and Brioso, P. 2016. First report of stem canker caused by Lasiodiplodia subglobosa on Carya illinoinensis in Brazil. Plant Dis. 100:1016.

Punithalingam, E. 1980. Plant Diseases Attributed to Botryodiplodia theobromae. Pat. J. Cramer, Vaduz.

Rodríguez-Gálvez, E., Guerrero, P., Barradas, C., Crous, P. W., and Alves, A. 2017. Phylogeny and pathogenicity of Lasiodiplodia species associated with dieback of mango in Peru. Fungal Biol. 121:452-465.

Rodríguez-Gálvez, E., Maldonado, E., and Alves, A. 2015. Identification and pathogenicity of Lasiodiplodia theobromae causing dieback of table grapes in Peru. Eur. J. Plant Pathol. 141:477-489.
Ronquist, F., Teslenko, M., van der Mark, P., Ayres, D. L., Darling, A., Höhna, S . Larget, B., Liu, L., Suchard, M. A., and Huelsenbeck, J. P. 2012. MrBayes v. 3.2: Efficient Bayesian phylogenetic inference and model choice across a large model space. Syst. Biol. 61:539-542.

Rosado, A. W. C., Machado, A. R., Freire, F. C. O., and Pereira, O. L. 2016 Phylogeny, identification, and pathogenicity of Lasiodiplodia associated with postharvest stem-end rot of coconut in Brazil. Plant Dis. 100:561-568.

Sakalidis, M. L., Ray, J. D., Lanoiselet, V., Hardy, G. E. S. J., and Burgess, T. I. 2011. Pathogenic Botryosphaeriaceae associated with Mangifera indica in the Kimberley Region of Western Australia. Eur. J. Plant Pathol. 130: 379-391.

Sandoval-Sánchez, M., Nieto-Ángel, D., Sandoval-Islas, J., Téliz-Ortiz, D. Orozco-Santos, M., and Silva-Rojas, H. V. 2013. Fungi associated to stem-end rot and dieback of mango (Mangifera indica L.). Agrociencia 47:61-73.

SIAP. 2013. Servicio de Información Agroalimentaria y Pesquera (SIAP). https:// www.gob.mx/siap.

Slippers, B., Boissin, E., Phillips, A. J. L., Groenewald, J. Z., Lombard, L., Wingfield, M. J., Postma, A., Burgess, T., and Crous, P. W. 2013. Phylogenetic lineages in the Botryosphaeriales: A systematic and evolutionary framework. Stud. Mycol. 76:31-49.

Slippers, B., Roux, J., Wingfield, M. J., van der Walt, F. J. J., Jami, F., Mehl, J. W. M., and Marais, G. J. 2014. Confronting the constraints of morphological taxonomy in the Botryosphaeriales. Persoonia 33:155-168.

Slippers, B., and Wingfield, M. J. 2007. Botryosphaeriaceae as endophytes and latent pathogens of woody plants: Diversity, ecology and impact. Fungal Biol. Rev. 21:90-106.

Staden, R., Beal, K. F., Bonfield, J. K. 1998. The Staden package, 1998. Pages 115-130 in: Bioinformatics Methods and Protocols. S. Misener and S. A. Krawetz, eds. Humana, New York.

Stamatakis, A. 2014. RAxML version 8: A tool for phylogenetic analysis and postanalysis of large phylogenies. Bioinformatics 30:1312-1313.

Trakunyingcharoen, T., Cheewangkoon, R., To-anun, C., Crous, P. W., van Niekerk, J. M., and Lombard, L. 2014. Botryosphaeriaceae associated with diseases of mango (Mangifera indica). Australas. Plant Pathol. 43: $425-438$

Trakunyingcharoen, T., Lombard, L., Groenewald, J. Z., Cheewangkoon, R., Toanun, C., and Crous, P.W. 2015. Caulicolous Botryosphaeriales from Thailand. Persoonia 34:87-99.

Uc-Várguez, A., López-Puc, G., Góngora-Canul, C. C., Martinez-Sebastián, G., and Aguilera-Cauich, E. A. 2017. Spatio-temporal spread of foot rot (Lasiodiplodia theobromae) in Jatropha curcas L. plantations in Yucatan, Mexico. Eur. J. Plant Pathol. 150:991-1000.

Úrbez-Torres, J. R., Leavitt, G. M., Guerrero, J. C., Guevara, J., and Gubler, W. D 2008. Identification and pathogenicity of Lasiodiplodia theobromae and Diplodia seriata, the causal agents of bot canker disease of grapevines in Mexico. Plant Dis. 92:519-529.

Vaidya, G., Lohman, D. J., and Meier, R. 2011. SequenceMatrix: Concatenation software for the fast assembly of multi-gene datasets with character set and codon information. Cladistic 27:171-180.

Vásquez-López, A., Mora-Aguilera, J. A., Cárdenas-Soriano, E., and Téliz-Ortiz, D. 2009. Etiología e histopatología de la muerte descendente de árboles de mamey [Pouteria sapota (Jacq.) H. E. Moore y Stearn] en el estado de Guerrero, México. Agrociencia 43:717-728.

White, T. J., Bruns, T., Lee, S., and Taylor, J. 1990. Amplification and direct sequencing of fungal ribosomal RNA genes for phylogenetics. Pages 315-322 in: PCR Protocols: A Guide to Methods and Applications. M. A Innis, D. H. Gelfand, J. J. Sninsky, and T. J. White, eds. Academic Press, San Diego, CA.

Yang, T., Groenewald, J. Z., Cheewangkoon, R., Jami, F., Abdollahzadeh, J., Lombard, L., and Crous, P. W. 2017. Families, genera, and species of Botryosphaeriales. Fungal Biol. 121:322-346.

Zhang, H., Wei, Y. X., Qi, Y. X., Pu, J. J., and Liu, X. M. 2018. First report of Lasiodiplodia brasiliense associated with stem-end rot of mango in China Plant Dis. 102:679.

Zhou, Y., Gong, G., Cui, Y., Zhang, D., Chang, X., Hu, R., Liu, N., and Sun, X. 2015. Identification of Botryosphaeriaceae species causing kiwifruit rot in Sichuan Province, China. Plant Dis. 99:699-708. 